\title{
The use of Location Based Instagram Data for Tourism Potential Analysis in Kabupaten Gunung Kidul
}

\author{
Muhammad Irham Akbar Hasri, Purnama Budi Santosa \\ Department of Geodetic Engineering, Faculty of Engineering, Universitas Gadjah Mada, INDONESIA
}

\section{Article History:}

Received 31 August 2018

Received in revised form 19 September 2018

Accepted 19 September 2018

Available online 25 September 2018

\section{Keywords:}

big data, social media, Instagram, Carto Builder, Gunung Kidul, tourism, spatial analysis

Corresponding Author:

Purnama Budi Santosa

Email: purnamabs@ugm.ac.id

\begin{abstract}
Gunung Kidul Regency is one of five regencies in Yogyakarta Province which is rich of natural tourism destination objects. Each tourism object has its own potential and characteristic that distinguishes one with other tourism objects. However, the tourism potency have not been exposed to public properly, and the local government has not sufficiently use the data of visitors as the basis for planning and development of tourism objects in Gunung Kidul Regency. This research tries to evaluate the use of BIG DATA, especially social media data, to analyze the tourism potency based on the public opinions and visits. For this purpose, Instagram data was utilized as the main data for the analysis. The data was collected between December 18, 2017 to February 3, 2018 using Instagram API. The data then was pre-processed to clear or filter the duplication data, to filter the data based on selective location or study area namely Gunung Kidul Regency, as well as to filter the data which match with the topic of the research namely "tourism". Some analysis then was conducted, namely spatial analysis, statistical analysis, and caption analysis. The spatial and statistical analysis were aimed to find spatial pattern of tourists visits at several locations in the form of spatial density of each tourism destinations with respect to temporal aspect. Analysis of captions is done by filtering Instagram data by using some keywords that can indicate tourism potency. Data was visualized using Carto Builder. Results show that some effort is needed to utilize the Instagram data for this purpose. The data is efficient and effective to be used to visualize spatial-temporal pattern of visitors at tourism destinations, as well as to understand tourism destinations objects potency in Gunung Kidul Regency. However, this analysis cannot be done in real time due to a limitation in collecting data from Instagram API.
\end{abstract}

(C) Author(s) 2018. This is an open access article under the Creative Commons Attribution-ShareAlike 4.0 International License (CC BY-SA 4.0).

\section{Pendahuluan}

Kabupaten Gunung Kidul memiliki objek wisata yang beragam. Keberagaman ini didukung oleh adanya kekayaan alam berupa pantai, goa, bukit, pegunungan, tempat bersejarah, serta desa wisata yang melimpah. Dengan visi rencana pembangunan jangka menengahnya sebagai daerah tujuan wisata yang terkemuka dan berbudaya (Pemerintah Kabupaten Gunung Kidul, 2016), Kabupaten Gunung Kidul berencana mengoptimalkan potensi dan kekayaan pariwisatanya. Kabupaten yang terletak di Provinsi Daerah Istimewa Yogyakarta (DIY) ini terdiri atas 18 Kecamatan dan 144 Kelurahan, dengan Kecamatan Wonosari sebagai pusat pemerintahannya. Sebagian besar daerahnya merupakan daerah perbukitan dan pegunungan kapur. Selain daerah perbukitan dan pegunungan, Kabupaten Gunung Kidul juga memiliki pantai, goa, tempat bersejarah, serta desa wisata. Setiap objek wisata memiliki potensinya masing-masing yang beragam. Untuk mengetahui potensi tersebut biasanya dilakukan survei langsung terhadap objek wisata tersebut. Namun, untuk melakukan hal tersebut pada daerah yang memiliki objek wisata beragam akan membutuhkan waktu yang lama.

Perkembangan teknologi membuat hidup semakin lebih mudah. Namun, hadirnya media sosial di dunia mengubah budaya manusia dalam berkomunikasi. Kebiasaan berfoto, berpendapat, dan berkomentar melalui media sosial telah menjadi bagian dari kebiasaan manusia 
saat ini. Akibat dari kebiasaan ini media sosial dapat digunakan untuk memantau perkembangan tren yang ada di masyarakat. Penggunaan data media sosial untuk penelitian telah banyak dilakukan. Hal ini dikarenakan data media sosial mudah diperoleh dan jumlahnya yang melimpah. Data ini juga dapat diperoleh secara secara realtime maupun data terdahulu.

Beberapa penelitian yang telah dilakukan seperti Ferrari, dkk. (2011) mengenai ekstraksi pola urban menggunakan media sosial berbasis lokasi; Iqbal, dkk. (2013) mengenai penggunaan data media sosial untuk melakukan prediksi pemilihan pemimpin; serta Chae, dkk. (2012) mengenai analisis adanya kegiatan-kegiatan dan topik yang bersifat abnormal menggunakan data media sosial. Keanekaragaman data media sosial menyebabkan banyak peneliti yang melakukan penelitian terhadap data tersebut. Berbagai jenis topik telah diunggah pada media sosial, salah satunya mengenai pariwisata. Berdasarkan penelitian Shao (2017) media sosial dapat digunakan untuk melakukan ekstraksi dan analisis wilayah objek wisata di Kota Huangshan. Pada penelitian tersebut, data media sosial Sina Weibo digunakan untuk analisis. Berbeda dengan Shao (2017), Penelitian ini dilakukan dengan menggunakan data media sosial Instagram sebagai sumber data. Pemilihan Instagram sebagai sumber data dikarenakan banyaknya jumlah pengguna Instagram di Indonesia. Bahkan menurut Setyaningsih (2017) Terdapat 24 juta akun aktif media sosial Instagram di Indonesia.

Mengacu pada penelitian sebelumnya yang dilakukan oleh Hasri (2018), penelitian ini memiliki beberapa tujuan. Pertama, melakukan eksplorasi data Instagram berbasis lokasi agar dapat mengetahui analisis potensi wisata di Kabupaten Gunung Kidul. Kedua menggali kemampuan data dan analisis untuk mengetahui apakah analisis potensi wisata dapat dilakukan secara realtime. Sehingga dapat diperoleh potensi wisata berdasarkan hasil analisis data spasial dan non spasial pada data Instagram di Kabupaten Gunung Kidul. Selain itu, visualisasi dan analisis yang dihasilkan dapat digunakan sebagai sumber informasi dalam menentukan keputusan terkait pariwisata seperti besar retribusi, pembangunan fasilitas, dan perbaikan fasilitas berdasarkan data.

\section{Data dan Metodologi}

\subsection{Data dan Lokasi}

Data yang digunakan pada penelitian ini berupa data batas administrasi wilayah Kabupaten Gunung Kidul berformat shapefile dan data media sosial Instagram berbasis lokasi. Data batas administrasi shapefile digunakan untuk menentukan jumlah dan lokasi titik sampel. Titik sampel tersebut akan digunakan untuk memperoleh data media sosial Instagram. Data batas administrasi ini diperoleh dari Geoportal milik Provinsi DIY. Data media sosial didapatkan dari data yang diupload oleh wisatawan pada rentang waktu tanggal 18 Desember 2017 hingga 3 Februari 2018. Data akan diunduh dalam format JSON.

Kabupaten Gunung Kidul dipilih karena memiliki banyak lokasi objek wisata. Kabupaten ini merupakan salah satu kabupaten di Provinsi DIY. Kabupaten ini memiliki luas wilayah 1.485,36 km2 atau sekitar 46,63\% dari luas Provinsi DIY (Pemerintah Kabupaten Gunung Kidul, 2018). Wilayah Kabupaten Gunung Kidul terdiri dari 18 Kecamatan dan 144 Kelurahan, dengan Kecamatan Wonosari sebagai pusat pemerintahannya. Kabupaten Gunung Kidul berbatasan dengan beberapa kabupaten dan samudera meliputi:

- Kabupaten Klaten dan Kabupaten Sukoharjo (Provinsi Jawa Tengah) di sebelah utara.

- Kabupaten Wonogiri (Provinsi Jawa Tengah) di sebelah timur.

- Kabupaten Bantul dan Kabupaten Sleman (Provinsi DIY) di sebelah barat.

- Serta Samudera Hindia di sebelah selatan (dapat dilihat pada Gambar 2.1).

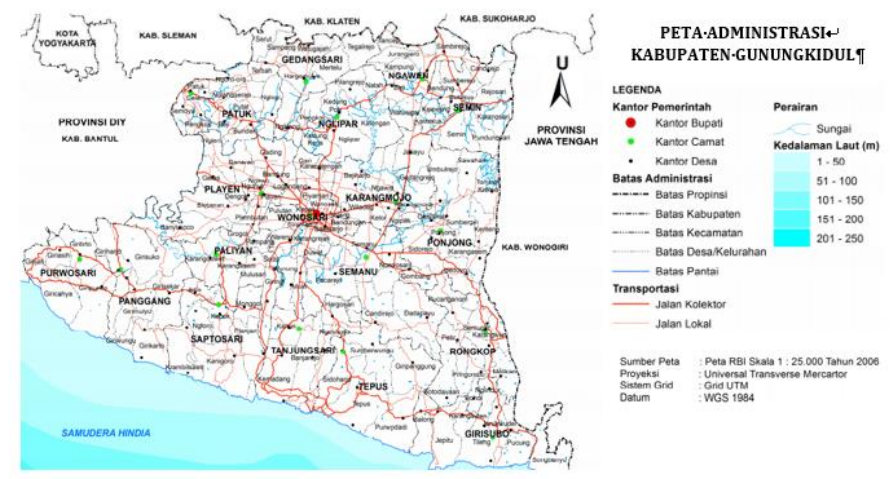

Gambar 2.1 Peta administrasi Kabupaten Gunung Kidul (Sumber: Pemerintah Kabupaten Gunung Kidul, 2016)

Kabupaten Gunung Kidul mempunyai beragam potensi perekonomian mulai dari perikanan, pertanian, peternakan, flora, fauna, industri, tambang, serta potensi pariwisata. Pariwisata yang berada di Kabupaten Gunung Kidul didukung oleh adanya kekayaan alam berupa pantai, goa, bukit, pegunungan, tempat bersejarah, serta desa wisata. Kabupaten Gunung Kidul mempunyai garis pantai dengan panjang $\pm 70 \mathrm{~km}$ (Pemerintah Kabupaten Gunung Kidul, 2016). Pantai ini membentang dari ujung barat hingga ujung timur. Salah satu pantai yang ada di Kabupaten Gunung Kidul ialah pantai Baron, Kukup, Drini, Sundak, Indrayanti, dan Pantai Krakal.

Selain pantai, Kabupaten Gunung Kidul juga memiliki wisata alam lainnya salah satunya goa dan bukit. Perbukitan yang berada di Kabupaten Gunung Kidul berupa perbukitan karst dengan jumlah \pm 40.000 bukit (Pemerintah Kabupaten Gunung Kidul, 2016). Kabupaten Gunung Kidul juga memiliki banyak goa karst yaitu sebanyak 119 gua (Pemerintah Kabupaten Gunung Kidul, 2016).

\subsection{Metodologi}

Data batas administrasi Kabupaten Gunung Kidul yang akan digunakan untuk kegiatan ini dapat diunduh melalui website geoportal Provinsi DIY (https://gis.jogjaprov.go.id). Data yang dipilih merupakan data batas administrasi berformat vektor dengan nama "Batas Desa DIY 2018". Dengan menggunakan software ArcGIS, lakukan penambahan layer tersebut dan ubah 
simbolisasinya untuk memudahkan identifikasi Kabupaten Gunung Kidul (dapat dilihat pada Gambar 2.2).

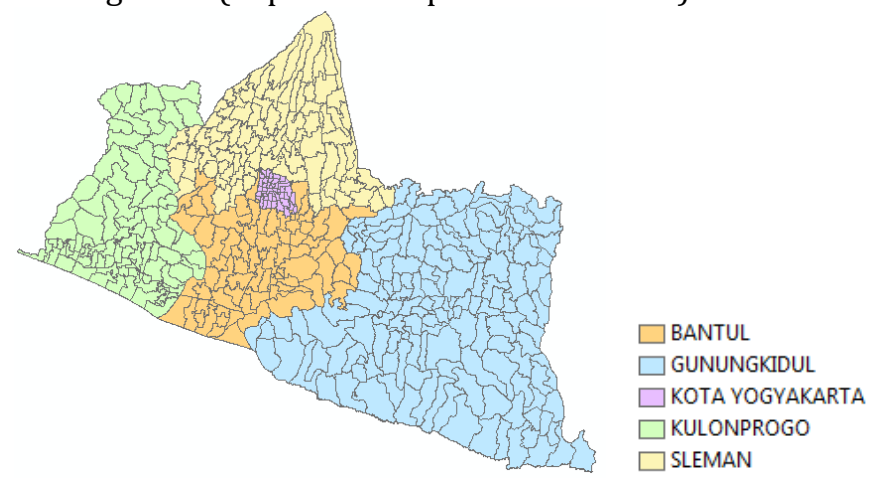

Gambar 2.2 Data batas administrasi desa DIY (Sumber: https://gis.jogjaprov.go.id).

Dari data tersebut dapat ditentukan titik sampel yang akan digunakan untuk memperoleh data media sosial pada Kabupaten Gunung Kidul. Titik sampel digunakan karena Instagram API mempunyai keterbatasan dalam pengumpulan datanya, khususnya dengan menggunakan akun tidak berbayar. Instagram API memiliki keterbatasan hanya dapat mengumpulkan data terbaru dari sebuah titik yang berada di radius $5.000 \mathrm{~m}$ (Toepke, 2015). Titik sampel dipilih secara acak dengan ketentuan jarak <= $10.000 \mathrm{~m}$ dari titik sampel lain (dapat dilihat pada Gambar 2.3). Pembuatan titik sampel dapat dilakukan secara manual atau dengan Create random points pada ArcGIS.

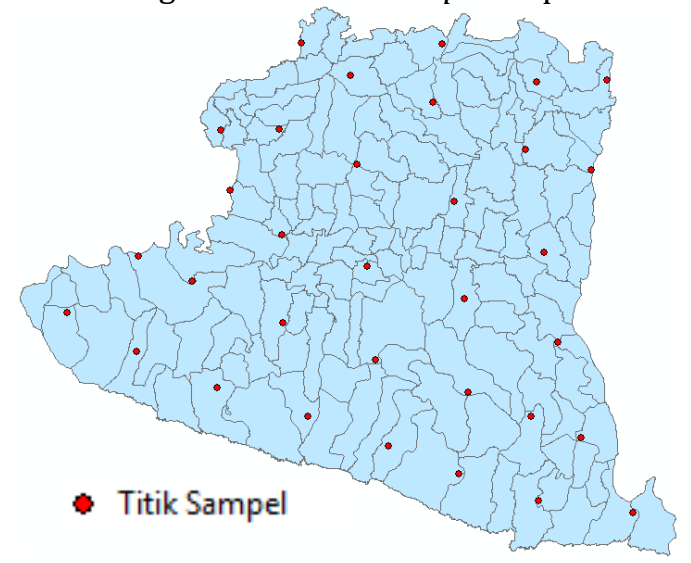

Gambar 2.3 Sebaran 33 titik sampel yang digunakan.

Data diunduh dengan menggunakan Instagram API, yang dapat dilihat pada website resminya. Application Programming Interface (API) merupakan sebuah alat yang membuat data sebuah website dapat dipahami oleh komputer (Cooksey, 2014). Melalui Instagram API peneliti dapat memperoleh data-data Instagram. Namun, untuk memperoleh data di seluruh Kabupaten Gunung Kidul, pengumpulan data dilakukan sebanyak jumlah titik sampel yang ditentukan pada langkah sebelumnya selama waktu pengumpulan data (18 Desember 2017 hingga 3 Februari 2018). Setiap data hasil pengumpulan dapat disimpan dalam format JSON.

Untuk mempermudah pengolahan data, data dapat dikonversi menjadi data tabel. Proses konversi data dilakukan dengan menggunakan bahasa Python. Program akan mengkonversi data menjadi 1 data tabel per data satu hari. Skrip ini terdiri dari dua bagian, yaitu bagian untuk membaca file berformat JSON dan bagian untuk menyimpan file menjadi format CSV. Penggunaan skrip VAR = json.load(open(“NAMA_FILE.txt")) digunakan untuk membaca file berformat JSON yang disimpan dalam file teks. Data yang telah terbaca akan disimpan pada sebuah variabel VAR. Variabel VAR akan dipisahkan per kolom dan disimpan pada file berformat CSV. Sebelum menyimpan, file berformat CSV akan dibuat dengan menggunakan skrip VAR_CSV=open(“NAMA_FILE.csv",'w',encoding='utf-8'). File CSV yang terbentuk akan disimpan pada variabel VAR_CSV. Skrip VAR_CSV.writerow(VAR_DATA), digunakan untuk menambahkan baris pada file CSV yang disimpan pada variabel VAR_DATA dengan variabel yang berisikan data Instagram.

Setelah data selesai dikonversi, selanjutnya penghilangan data duplikasi dengan menggunakan bantuan salah satu software Microsoft Office Excel. Dengan memilih ID post sebagai acuan, duplikasi dapat dihilangkan dengan menggunakan Remove Duplicates pada Microsoft Office Excel. Setelah semua data telah dihilangkan duplikasinya, maka data tabel per hari dapat disatukan menjadi 1 data format tabel. Dan dicek kembali apakah sudah tidak memiliki data duplikat. Setelah data tidak memiliki data duplikat, data kemudian dibersihkan dari data yang tidak menunjukkan lokasi wisata. Hal ini dilakukan dengan melakukan filtering pada kolom nama lokasi wisata dipilih satu per satu nama-nama yang bukan nama lokasi wisata.

Data kemudian diimpor ke dalam software ArcGIS untuk dihilangkan data yang berada di luar Kabupaten Gunung Kidul. Hal ini dilakukan dengan memanfaatkan data koordinat post Instagram dan data batas administrasi DIY. Kemudian dari hasil ArcGIS data kemudian dikoversi kembali menjadi data tabel dengan mengekspor data dari ArcGIS. Setelah menjadi data tabel, dilakukan penambahan informasi baru seperti waktu, nama objek wisata, serta tipe objek wisata, serta latitude dan longitude baru. Informasi waktu ditambahkan karena data waktu pada post Instagram dalam format unix timestamp. Unix timestamp merupakan jumlah detik yang dihitung sejak waktu 00:00:00 tanggal 1 Januari 1970 (Chen, dkk., 2016). Sehingga perlu adanya konversi waktu dengan menggunakan formula $=(((C E L L / 60) / 60) / 24)+(\operatorname{DATE}(1970,1,1)) . \quad$ Berdasarkan formula tersebut, CELL merupakan sel pada tabel yang berisikan nilai unix timestamp. Berdasarkan Cvetojevic, dkk. (2016) pergeseran antara lokasi objek sebenarnya dengan lokasi dari Instagram mencapai $2 \mathrm{~m}$ sampai $24 \mathrm{~km}$ (dengan median $85 \mathrm{~m}$ dan rata-rata $635 \mathrm{~m}$ ). 52\% dari lokasi tersebut berada kurang dari $100 \mathrm{~m}$ dari lokasi sebenarnya dan $14 \%$ dari lokasi tersebut berada lebih dari $1 \mathrm{~km}$ dari lokasi sebenarnya (Cvetojevic, dkk., 2016). Sehingga perlu ditambahkan atribut koordinat baru. Penambahan kolom latitude dan longitude yang sesuai dilakukan dengan menyesesuaikan dengan data koordinat yang ada pada Google Maps.

Visualisasi data dilakukan dengan menggunakan Carto Builder. Data tabel yang sebelumnya diolah diimporkan ke 
dalam Carto Builder. Pada Carto Builder style atau tampilan pada peta dapat diatur dengan mudah. Salah satu style yang digunakan ialah animated heatmap. Density Analysis atau disebut juga dengan heatmap merupakan salah satu analisis SIG yang menggunakan kerapatan data yang menghasilkan data raster. Berdasarkan Mitchell (1999) SIG akan melakukan perhitungan nilai densitas setiap sel pada raster. Dari hasil analisis ini dihasilkan raster dengan gradasi nilai sel (dapat dilihat pada Gambar 2.4),

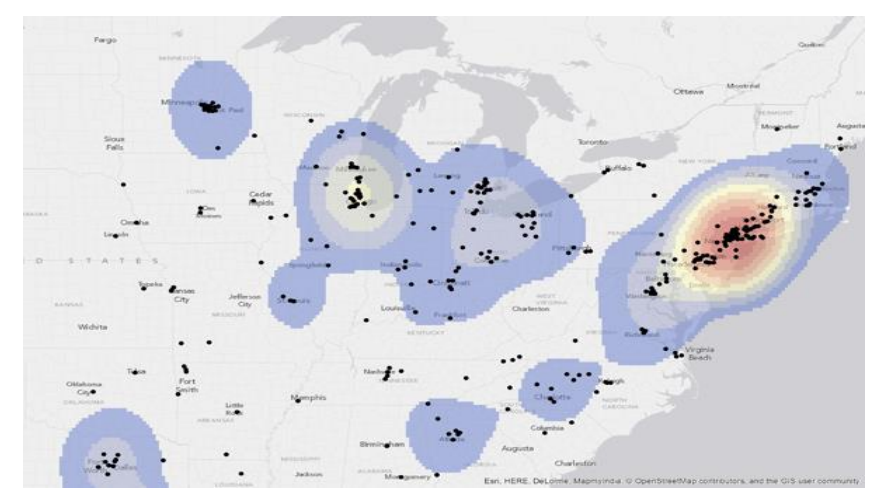

Gambar 2.4 Tampilan analisis heatmap (Dempsey, 2014).

Penambahan widget pada Carto Builder juga dapat membantu dalam proses analisis berikutnya. Dalam penggunaan style khususnya simbol harus memperhatikan variabel tampak. Penentuan simbol yang tepat dapat mempermudah dalam memahami peta. Variabel tampak didasarkan pada kemampuan dasar mata untuk membedakan suatu simbol dari simbol lainnya (dapat dilihat pada Gambar 2.5). Untuk menggunakan variabel tampak harus diketahui dahulu tipe data tersebut.

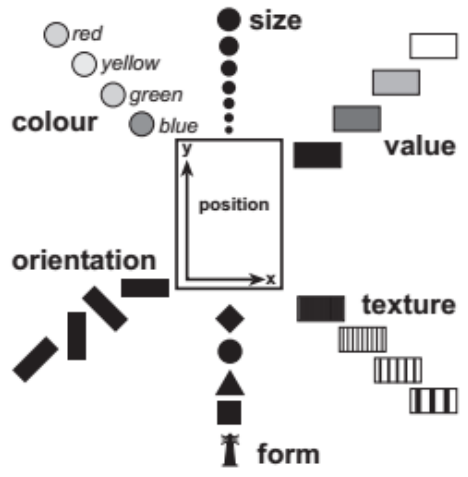

Gambar 2.5 Ketujuh variabel tampak (Elzakker, 2004).

Setelah visualisasi telah selesai, peta dapat dilakukan analisis. Analisis yang dilakukan merupakan analisis spasial, analisis statistik, dan analisis berdasarkan caption. Seluruh analisis akan dilakukan berdasarkan ESDA dan EDA. Exploratory Spatial Data Analysis (ESDA) merupakan analisis menggunakan gambar visual (termasuk peta), penjelasan statistik, dan algoritma perhitungan untuk dapat berinteraki dengan data analisis, mengidentifikasi pola, mencari hipotesis, dan menemukan informasi yang tidak diketahui atau tidak terduga (Guo, 2016). ESDA merupakan pengembangan dari Exploratory Data Analysis (EDA). EDA biasanya menggunakan metode dan grafik statistik seperti box plot, histogram, scatter plot, parallel coordinate plot, dan lain-lain. Grafik yang digunakan pada EDA juga disesuaikan dengan data yang akan dianalisis. Analisis spasial dilakukan berdasarkan ESDA yaitu dengan menggunakan hasil heatmap yang divisualisasikan pada peta. Analisis statistik dilakukan berdasarkan data post yang telah diolah pada kegiatan ini. Analisis diperoleh dari grafik yang divisualisasikan pula pada grafik di peta. Grafik yang digunakan disesuaikan dengan tipe data dan jenis kategori yang dipilih sesuai EDA. Analisis terakhir yaitu analisis berdasarkan caption. Caption biasanya dicantumkan pada post Instagram. Analisis ini dilakukan dengan memfilter data post Instagram menggunakan kata kunci tertentu yang berhubungan dengan potensi objek wisata.

\section{Hasil dan Pembahasan}

Dari seluruh tahapan yang telah dilakukan pada Bab sebelumnya, dihasilkan sebuah visualisasi dari post Instagram berbasis lokasi terkait objek wisata. Visualisasi ini menampilkan 2 data yaitu data spasial dan data statistik. Data spasial yang ditampilkan berupa objek wisata dalam bentuk titik dan data post Instagram dalam bentuk heatmap. Sedangkan data statistik yang ditampilkan yaitu berupa 2 buah grafik statistik. Kemudian dari visualisasi ini dapat dilakukan analisis untuk memperoleh informasi baru terkait objek wisata. Bab ini akan membahas lebih rinci mengenai hasil dan pembahasan terkait pelaksanaan dari kegiatan penelitian ini.

\subsection{Hasil Desain Simbologi}

Simbol yang akan ditampilkan pada peta harus didesain terlebih dahulu. Desain simbol menggunakan variabel tampak. Untuk simbolisasi, data ditentukan terlebih dahulu simbol dasar, jenis data, dan jenis pemahamannya (asosiatif, selektif, ordered, dan kuantitatif). Setelah diketahui, kemudian ditentukan variabel tampak untuk data tersebut.

Tabel 3.1 Hasil desain simbol berdasarkan variabel

\begin{tabular}{cccccc} 
Data & $\begin{array}{c}\text { Simbol } \\
\text { Dasar }\end{array}$ & $\begin{array}{c}\text { Jenis } \\
\text { Simbol }\end{array}$ & $\begin{array}{c}\text { Tipe } \\
\text { Data }\end{array}$ & $\begin{array}{c}\text { Jenis } \\
\text { Pemaham } \\
\text { an }\end{array}$ & $\begin{array}{c}\text { Variab } \\
\text { el } \\
\text { tampak }\end{array}$ \\
\hline $\begin{array}{c}\text { Point Of } \\
\text { Interest } \\
\text { (POI) }\end{array}$ & Titik & Piktoria & Nomina & Asosiatif & $\begin{array}{c}\text { Bentuk } \\
\text { dan }\end{array}$ \\
& & $l$ & $l$ & & Warna
\end{tabular}

Berdasarkan pada Tabel 3.1, dihasilkan desain simbol untuk POI. Simbol dasar yang disajikan berupa titik dengan jenis simbol piktorial. Piktorial dipilih untuk memudahkan identifikasi objek wisata pada peta. Data POI memiliki nilai atribut yang berbeda, tanpa memiliki aspek yang membuat lebih penting dibandingkan lainnya. Tipe data seperti ini termasuk dalam tipe data nominal dan jenis pemahaman asosiatif. Variabel tampak untuk POI menggunakan bentuk dan warna. Kedua variabel ini dipilih untuk mempermudah identifikasi objek wisata. Simbol didesain berdasarkan variabel tampak tersebut 
dan menghasilkan simbol yang ditunjukkan pada Tabel 3.2. Bentuk simbol dipilih disesuaikan dengan simbol-simbol yang mudah mengidentifikasikan wisata tersebut.

Tabel 3.2 Pertimbangan dalam mendesain simbol

\begin{tabular}{|c|c|c|c|}
\hline Data & $\begin{array}{c}\text { Tipe } \\
\text { Objek }\end{array}$ & Simbol Dasar & Jenis Simbol \\
\hline & $\begin{array}{c}\text { Air } \\
\text { Terjun }\end{array}$ & $\begin{array}{l}\text { Menggambarkan } \\
\text { tebing dan aliran air }\end{array}$ & $\begin{array}{l}\text { Biru : Warna yang } \\
\text { identik dengan air }\end{array}$ \\
\hline & $\begin{array}{c}\text { Bukit } \\
\text { atau } \\
\text { Gunung }\end{array}$ & $\begin{array}{l}\text { Menggambarkan } \\
\text { simbol gunung }\end{array}$ & $\begin{array}{l}\text { Merah : warna yang } \\
\text { melambangkan } \\
\text { kekuatan }\end{array}$ \\
\hline & $\begin{array}{c}\text { Desa } \\
\text { Wisata }\end{array}$ & $\begin{array}{l}\text { Menggambarkan } \\
\text { desa dengan rumah- } \\
\text { rumah yang } \\
\text { bersampingan }\end{array}$ & $\begin{array}{l}\text { Hijau : } \\
\text { Menggambarkan } \\
\text { keasrian dan } \\
\text { keramahan desa }\end{array}$ \\
\hline & Goa & $\begin{array}{l}\text { Menggambarkan } \\
\text { segitiga dengan } \\
\text { lubang yang seperti } \\
\text { mulut goa }\end{array}$ & $\begin{array}{l}\text { Ungu : warna yang } \\
\text { identik dengan } \\
\text { warna gelap selain } \\
\text { hitam }\end{array}$ \\
\hline & $\begin{array}{l}\text { Hutan } \\
\text { atau } \\
\text { Kebun } \\
\end{array}$ & $\begin{array}{l}\text { Menggambarkan } \\
\text { vegetasi secara } \\
\text { umum }\end{array}$ & $\begin{array}{l}\text { Hijau : warna yang } \\
\text { identik dengan } \\
\text { vegetasi }\end{array}$ \\
\hline & Pantai & $\begin{array}{l}\text { Menggambarkan } \\
\text { salah satu aktivitas } \\
\text { di pantai (berenang) }\end{array}$ & $\begin{array}{l}\text { Biru : Warna yang } \\
\text { identik dengan air }\end{array}$ \\
\hline & Telaga & $\begin{array}{l}\text { Menggambarkan air } \\
\text { secara umum untuk } \\
\text { menggambarkan } \\
\text { tempat air } \\
\text { berkumpul }\end{array}$ & $\begin{array}{l}\text { Biru : Warna yang } \\
\text { identik dengan air }\end{array}$ \\
\hline & $\begin{array}{l}\text { Wisata } \\
\text { Lainnya }\end{array}$ & $\begin{array}{l}\text { Menggambarkan } \\
\text { objek wisata lain } \\
\text { yang beragam }\end{array}$ & $\begin{array}{l}\text { Kuning : Warna yang } \\
\text { melambangkan } \\
\text { keceriaan }\end{array}$ \\
\hline
\end{tabular}

\subsection{Hasil Visualisasi}

Visualisasi yang dihasilkan berupa peta online interaktif. Visualisasi ini dibuat dengan menggunakan Carto Builder dan Hypertext Markup Language (HTML). Terdapat 2 layer pada peta yaitu Data post Instagram, dan POI. Untuk layer data post Instagram ditampilkan dalam bentuk heatmap. Sedangkan pada layer POI ditampilkan dalam bentuk titik menggunakan simbol berdasarkan tipe wisatanya. Hasil visualisasi ditunjukan pada Gambar 3.1. Hasil visualisasi dapat diakses melalui link URL http://irham24.github.io/PetaPotensiWisataGunungkidul atau http://ugm.id/PPWG.

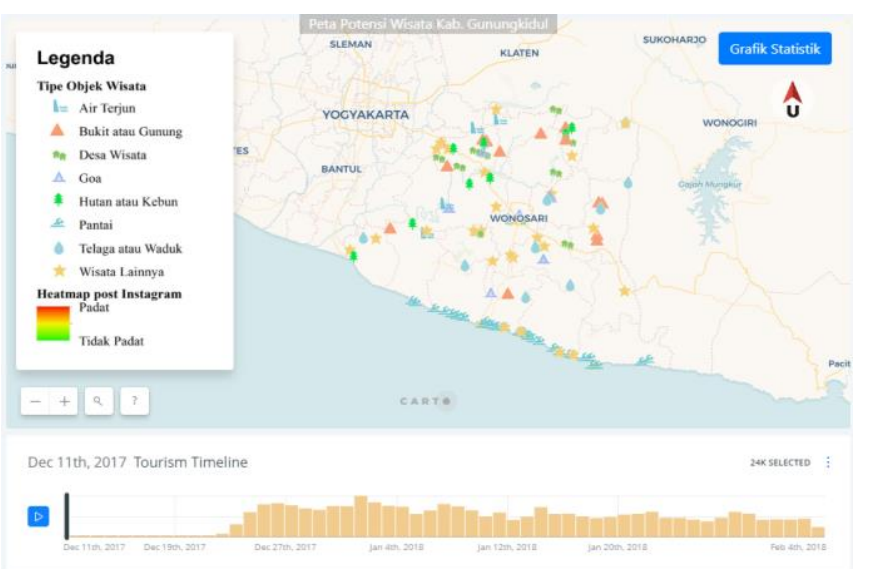

Gambar 3.1. Hasil visualisasi data Instagram (Sumber: hasil pengolahan penulis)
Dari hasil visualisasi tersebut terdapat beberapa fitur, yaitu legenda, animasi heatmap, dan grafik statistik. Legenda ditampilkan dengan menggunakan gambar yang disisipkan menggunakan HTML. Grafik statistik ditampilkan pada peta, dengan mengklik tombol yang berada di pojok kanan atas peta.

\subsection{Analisis Spasial}

Analisis dilakukan dengan memperhatikan heatmap yang ditampilkan diatas peta. Dari heatmap tersebut terlihat bahwa data terpadat selama waktu penelitian terdapat pada daerah pantai. Kepadatan dapat dilihat dari warna heatmap yang ditampilkan (dapat dilihat pada Gambar 3.2). Walaupun warna hijau menunjukkan daerah tersebut tidak padat, namun tidak selalu berarti terdapat post di daerah tersebut. Karena dalam algoritma pembentukan gradasi heatmap ditentukan dengan radius tertentu.

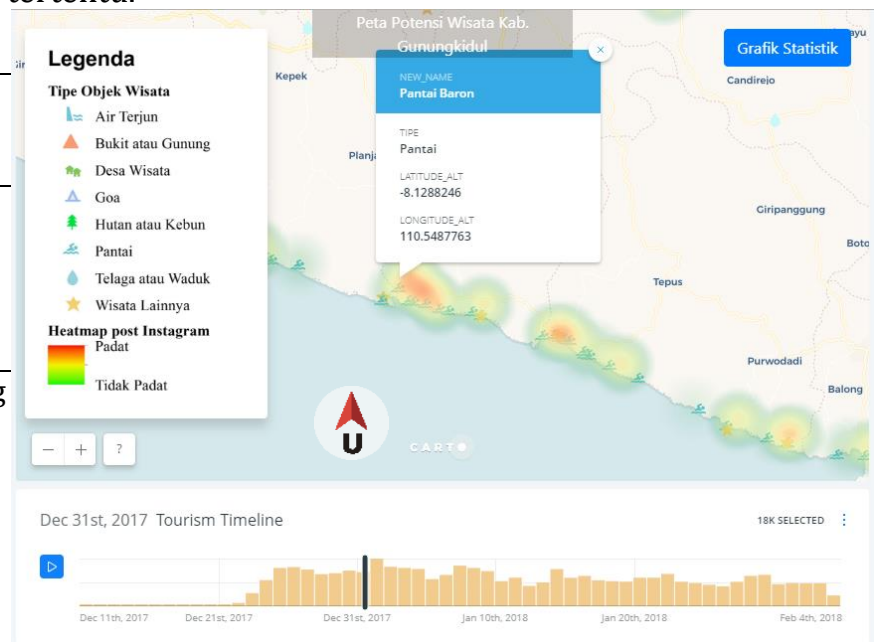

Gambar 3.2 Contoh kepadatan data yang ditunjukan di Pantai Baron pada tanggal 31 Desember 2017 (Sumber: hasil pengolahan penulis).

Menurut Koordinator Satlinmas Rescue Istimewa Wilayah II Gunung Kidul jumlah pengunjung pantai meningkat 50\% hampir di seluruh pantai saat menjelang pergantian tahun 2018 (Istiqomah, K., 2017). Peningkatan jumlah data juga terlihat pada peta yang ditunjukan pada peta hasil visualisasi. Peningkatan ini ditunjukan dari bertambahnya warna merah pada heatmap di beberapa lokasi wisata khususnya lokasi wisata pantai. Berdasarkan definisi potensi wisata oleh Yoeti (1983) dalam Sari (2015), potensi wisata ialah segala sesuatu yang terdapat di daerah tujuan wisata, dan merupakan daya tarik agar orang-orang tersebut mau datang berkunjung ke tempat tersebut. Dari definisi tersebut, kepadatan ini menunjukan bahwa lokasi wisata tersebut memiliki daya tarik wisatawan atau potensi wisata.

\subsection{Analisis Statistik}

Berdasarkan data post Instagram yang dikumpulkan, dihasilkan 3 grafik statistik. Pertama grafik pie, Grafik ini digunakan untuk menampilkan data berdasarkan tipe objek wisata. Berdasarkan grafik pie yang ditunjukan pada 
Gambar 3.3, objek wisata bertipe pantai mendominasi data dengan presentase $72.5 \%$. Namun, berdasarkan Sekretaris Dinas Pariwisata Gunung Kidul, kawasan pantai dikunjungi sekitar 20.000 orang, sedangkan untuk destinasi lainnya terdapat 10.000-an pengunjung (Kurniawan, D., 2018). Dari kedua informasi tersebut dapat disimpulkan kunjungan pantai mendominasi tipe wisata lainnya.

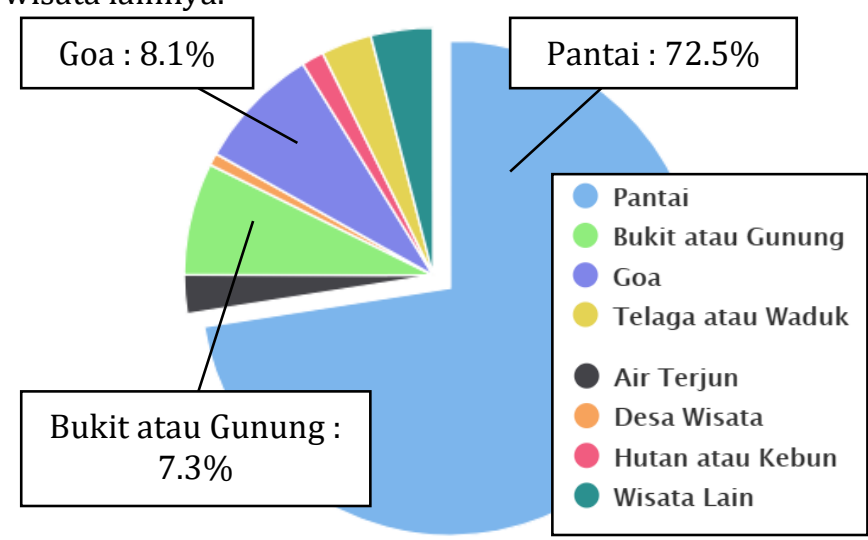

Gambar 3.3. Grafik pie menunjukan pantai mendominasi dengan $72.5 \%$.

Grafik kedua berupa grafik stacked yang menampilkan grafik berdasarkan hari (dapat dilihat pada Gambar 3.4). Berdasarkan grafik tersebut data terbanyak berada di hari senin. Terdapat lebih dari 4000 post Instagram yang diupload pada hari senin. Dari jumlah post tersebut, sekitar 3000 post diantaranya merupakan post mengenai wisata pantai. Hal ini dapat dipengaruhi oleh tanggal 25 Desember (hari libur natal) dan 1 Januari 2018 yang berada pada hari Senin.

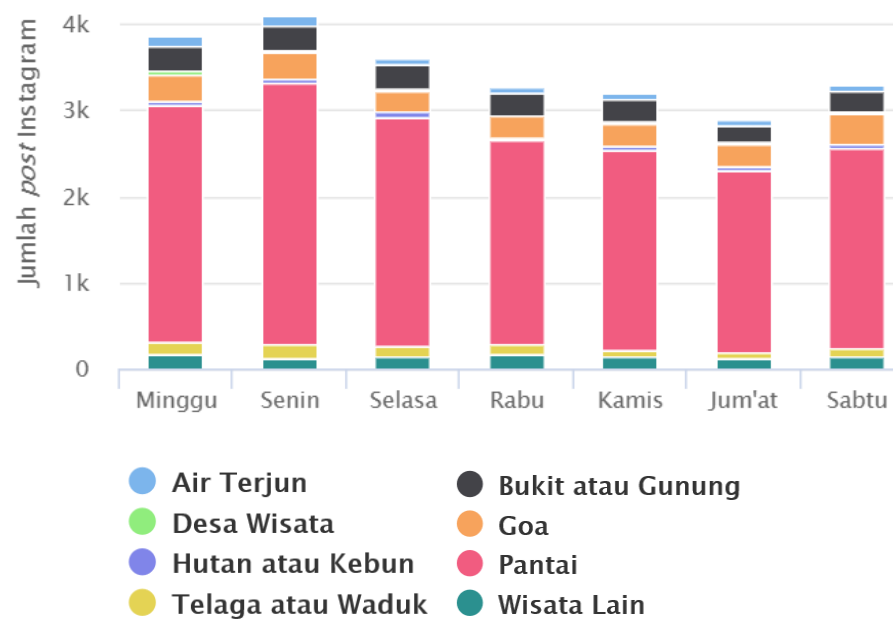

Gambar 3.4 Grafik stacked yang menunjukan hari senin sebagai hari terpadat.

Grafik ketiga yaitu grafik batang, grafik ini menampilkan jumlah post Instagram berdasarkan tanggal post tersebut di-upload. Melalui grafik ini, analisis dilakukan untuk mengetahui keterkaitan antara jumlah post dengan tanggal post tersebut di-upload. Selain itu grafik ini juga dapat menampilkan pola jumlah post terhadap tanggal upload post tersebut. Berdasarkan grafik tersebut, post terbanyak berada ditanggal 1 Januari 2018 yang berjumlah 951 post (dapat dilihat pada Gambar 3.5).
Hal ini dapat pengaruhi oleh tanggal yang bertepatan dengan libur tahun baru 2018.

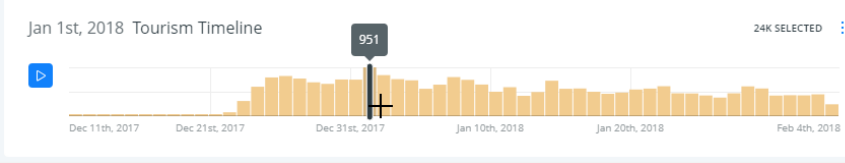

Gambar 3.5 Grafik batang yang menunjukkan data terbanyak.

\subsection{Analisis Berdasarkan Caption}

Analisis terakhir dilakukan berdasarkan caption yang dicantumkan pada post Instagram. Analisis ini menggunakan beberapa kata kunci yang dapat menampilkan potensi wisata tersebut. Berdasarkan definisi potensi wisata oleh Yoeti (1983), potensi wisata merupakan daya tarik yang dimiliki objek wisata. Salah satu daya tarik yang dimiliki objek wisata ialah keindahan dan aksesibilitas. Sehingga dipilihlah kata kunci seperti "bersih", "kotor", "indah", dan "jalan". Kata kunci tersebut digunakan untuk kata kunci pada proses filtering menggunakan software pengolah tabel. Pada proses filtering, caption dipilih secara manual yang benar-benar menyatakan potensi wisata. Berdasarkan hasil tersebut diperoleh beberapa lokasi yang mempunyai potensi dalam hal keindahan objek wisata. Objek wisata yang menunjukan potensi keindahan dengan kata kunci "bersih" atau "kotor" yaitu Pantai Watu Kodok, Pantai Ngetun, Pantai Gesing, Pantai Sadranan, Pantai Ngandong, Pantai Wohkudu, Air Terjun Sri Gethuk, Pantai Ngrenehan, dan Pantai Pok Tunggal. Air Terjun Sri Gethuk merupakan salah satu objek wisata yang dicantumkan kata kunci "bersih" atau "kotor" pada caption post Instagram yang ditunjukkan pada Gambar 3.6..

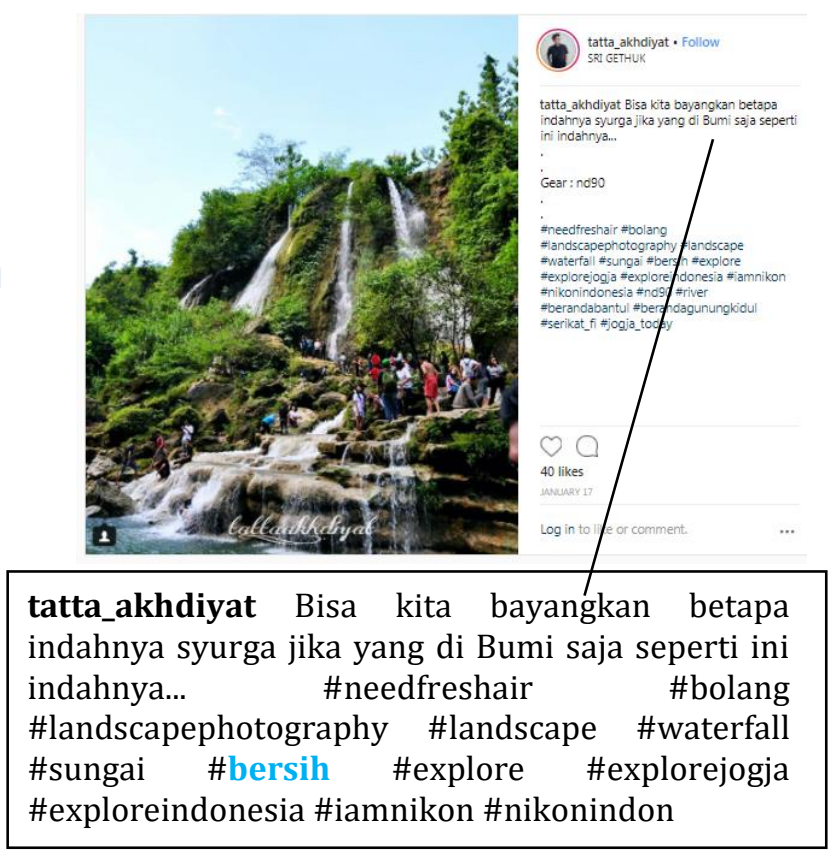

Gambar 3.6 Salah satu post yang menunjukan kata kunci "bersih" (Sumber: Instagram). 
Objek wisata yang menunjukan potensi aksesibilitas dengan kata kunci "jalan" yaitu Gua Pindul, Pantai Gesing, Pantai Timang, Pantai Watu Lumbung, Puncak Batara Sriten, Pantai Sedahan, dan Pantai Ngetun. Seluruh objek wisata yang disebutkan sebelumnya mendapatkan caption yang menyatakan buruknya akses menuju lokasi tersebut. Salah satunya ialah Pantai Ngentun yang ditunjukan pada caption berikut.

\section{izharhaqq Setelah jalan yg jelek} terdapat pantai yg bagus

Objek wisata yang menunjukan potensi keindahan dengan kata kunci "indah" yaitu Air Terjun Srigethuk, Baron Technopark, Bukit Bintang, Desa Wisata Mojo, Embung Nglanggeran, Geoforest Watu Payung Turunan, Geosite Ngingrong, Goa Jomblang, Gua Maria Tritis, Gua Pindul, Gua Rancang Kencono, Gunung Api Purba Nglanggeran, Gunung Gambar, Gunung Ireng, Hutan Wanagama, Jam Matahari Baron Techno Park, Kalisuci Cavetubing, Kebun Buah Nglanggeran, Pantai Baron, Pantai Butuh, Pantai Drini, Pantai Gesing, Pantai Indrayanti, Pantai Karakal, Pantai Kesirat, Pantai Krakal, Pantai Kukup, Pantai Ngandong, Pantai Ngedan, Pantai Ngetun, Pantai Nglolang, Pantai Ngobaran, Pantai Ngrenehan, Pantai Nguyahan, Pantai Pok Tunggal, Pantai Pulang Syawal, Pantai Sadranan, Pantai Sadranan Snorkeling, Pantai Sedahan, Pantai Sepanjang, Pantai Siung, Pantai Slili, Pantai Srakung, Pantai Sundak, Pantai Timang, Pantai Watu Kodok, Pantai Watu Lumbung, Pantai Wediombo, Pantai Wohkudu, Baron Techo Park, Pulau Timang, Puncak Batara Sriten, Taman Hutan Raya Bunder, Taman Bunga Amarylis Ngasemayu, Telaga Biru, dan Telaga Jonge. Pantai Wediombo mendapat 53 post yang menyatakan caption dengan kata kunci "indah". Salah satu caption tersebut seperti yang ditunjukkan pada Gambar 3.7.

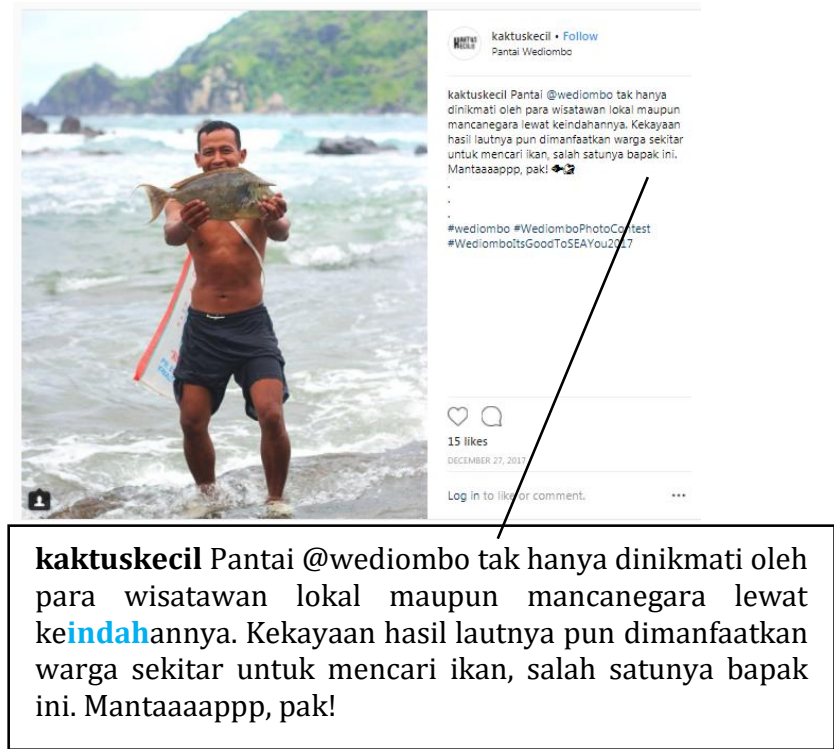

Gambar 3.7. Salah satu post yang menunjukkan kata kunci "indah" (Sumber Instagram).

\section{Kesimpulan}

Penelitian ini membuktikan bahwa analisis potensi wisata dapat dilakukan dengan data Instagram. Adanya beberapa parameter yang ada pada data Instagram dapat digunakan untuk melakukan analisis potensi tersebut. Analisis dapat dilakukan dengan berbagai metode, seperti analisis spasial (ESDA dengan heatmap), analisis statistik (EDA dengan grafik), dan analisis berdasarkan caption. Adanya data lokasi memungkinkan untuk mengetahui kepadatan wisatawan di lokasi wisata tersebut. Kepadatan tersebut dapat mengindikasikan suatu objek wisata memiliki daya tarik atau potensi. Selain jumlah dengan data caption yang ada, dapat diperoleh opini dari wisatawan yang dapat di-filter untuk memperoleh informasi potensi wisata tersebut berdasarkan pandangan wisatawan.

Namun, Analisis ini belum dapat dilakukan secara realtime, ini dikarenakan adanya limitasi pada saat pengumpulan data melalui Instagram API. Selain itu beberapa tahapan pada penelitian ini dilakukan secara manual. Tahapan tersebut seperti penambahan informasi baru pada data, visualisasi pada Carto Builder, pengaturan data yang akan ditampilkan pada grafik, serta proses filtering pada analisis ini. Sehingga analisis ini tidak dapat dilakukan secara realtime.

\section{Pernyataan Konflik Kepentingan}

Penulis menyatakan tidak ada konflik kepentingan dalam artikel ini (The authors declare no competing interest).

\section{Referensi}

Chae, J., Thom, D., Bosch, H., Jang, Y., Maciejewski, R., Ebert, D. S., \& Ertl, T. (2012). Spatiotemporal social media analytics for abnormal event detection and examination using seasonal-trend decomposition. In IEEE Conference on Visual Analytics Science and Technology 2012, VAST 2012 - Proceedings (pp. 143152).

Chen, C., Ma, J., Susilo, Y., Liu, Y., \& Wang, M. (2016). The promises of big data and small data for travel behavior (aka human mobility) analysis. TRANSPORTATION RESEARCH PART C, 68, 285-299. https://doi.org/10.1016/j.trc.2016.04.005

Cooksey, B. (2014). An Introduction to APIs. Zapier, Inc.

Cvetojevic, S., Juhasz, L., \& Hochmair, H. (2016). Positional Accuracy of Twitter and Instagram Images in Urban Environment. https://doi.org/10.1553/giscience2016_01_s191

Elzakker, C. P. J. M. van. (2004). The use of maps in the exploration of Geospatial data. Utrecht: University of Utrecht

Ferrari, L., Rosi, A., Mamei, M., \& Zambonelli, F. (2011). Extracting urban patterns from location-based social networks. Proceedings of the 3rd ACM SIGSPATIAL 
International Workshop on Location-Based Social Networks - LBSN'11, 1.

Guo, D. (2016). Exploratiry Spatial Data Analysis. https://doi.org/10.1002/9781118786352

Hasri, M. I. A. (2018). Analisis Potensi Wisata Menggunakan Data Instagram Berbasis Lokasi di Kabupaten Gunung Kidul. Universitas Gadjah Mada.

Iqbal, T., Mahmood, T., Amin, F., Lohanna, W., \& Mustafa, A. (2013). Mining Twitter Big Data to Predict 2013 Pakistan Election Winner. In IEEE (pp. 49-54).

Istiqomah, K. (2017). Kungjungan Wisatawan Pantai Gunung Kidul Meningkat 50\%. Retrieved from http://www.jatengpos.com/2017/12/kunjunganwisatawan-pantai-gunungkidul-meningkat-50881109 diakses pada 21 Mei 2018

Kurniawan, D. (2018). Sekitar 30.000 Wisatawan Padati Gunungkidul. Retrieved from http://www.jatengpos.com/2018/01/sekitar-30000-wisatawan-padati-gunungkidul-881501 diakses pada 30 Mei 2018

Mitchell, A. (1999). The ESRI guide to GIS analysis. Volume 1: Geographic patterns \& relationships. Annals of Physics, 54 87-88. https://doi.org/10.1017/CB09781107415324.004

Pemerintah Kabupaten Gunungkidul. (2016). Rencana Pembangunan Jangka Menengah Daerah Kabupaten Gunungkidul Tahun 2016-2021.

Pemerintah Kabupaten Gunungkidul. (2018). Kondisi Umum. Retrieved from http://gunungkidulkab.go.id/D74db63a914e6fb0f4445120c6fa44e6a-NR-100- 0.html diakses pada 29 Mei 2018

Pemerintah Kabupaten Gunungkidul. (2018). Visi, Misi dan Arah Kebijaksanaan. Retrieved from http://gunungkidulkab.go.id/D947db8881fd2f1e605a1fe29a8b6aa6c-NR-100$0 . h$ tml diakses pada 29 Mei 2018

Sari, D. M. (2015). Partisipasi Masyarakat dalam Mengembangkan Sarana Prasarana Kawasan Desa Wisata Borobudur. Semarang: Universitas Diponegoro.

Setyaningsih, L. (2017). Warga Pengguna Aktif Instagram di Indonesia Capai 45 Juta Terbesar di Asia Pasifik. Retrieved from http://wartakota.tribunnews.com/2017/07/26/war ga-pengguna-aktif-instagram-di-indonesia-capai-45juta-terbesar-di-asia-pasifik diakses pada 29 Mei 2018

Shao, H., Zhang, Y., \& Li, W. (2017). Computers , Environment and Urban Systems Extraction and analysis of city â€TM s tourism districts based on social media data. Computers, Environment and Urban Systems, 65, 66-78. https://doi.org/10.1016/j.compenvurbsys.2017.04. 010

Toepke, S. L., \& Starsman, R. S. (2015). Population Distribution Estimation of an Urban Area Using Crowd Sourced Data for Disaster Response. In Short Paper - Geospatial Data and Geographical Information Science Proceedings of the ISCRAM 2015 Conference Kristiansand, May 24-27 Palen, Büscher, Comes \& Hughes, eds. 